\title{
Spoiled for Choice during Cold Season? Habitat Use and Po- tential Impacts of the Invasive Silurus glanis L. in a Deep, Large and Oligotrophic Lake (Lake Maggiore, North Italy)
}

\author{
Vanessa De Santis ${ }^{1, *}$, Pietro Volta ${ }^{1}$ \\ 1 CNR-IRSA, Largo Tonolli 50, 28922 Verbania Pallanza, VB, Italy; vanessa.desantis@irsa.cnr.it (V.D.S.); \\ pietro.volta@cnr.it (P.V.). \\ * Correspondence: vanessa.desantis@irsa.cnr.it;
}

\begin{abstract}
Ecological information of invasive alien species are crucial for their effective management. However, they are often lacking in newly invaded ecosystems. This is the case of the European catfish Silurus glanis L. in Lake Maggiore where the species is present since 1990 but no scientific information are available on its ecology. To start filling this knowledge gap, 236 catfish $(67 \mathrm{~cm}$ to $150 \mathrm{~cm}$ of total length) were collected, measured, and dissected for stomach content analyses from three localities and in two habitats (littoral vs. pelagic) in late autumn/early winter. NPUE and BPUE (individuals and biomass $(\mathrm{g})$ per unit effort $\left(\mathrm{m}^{2}\right)$ ) of catfish was generally higher in littoral (NPUE > 0.01; BPUE > 96) than pelagic habitats (NPUE < 0.009; BPUE < 114) but catfish had, on average, larger sizes in pelagic habitats. Overall, 581 individual prey items were recorded belonging to12 taxa. Pelagic catfish specialized their diet exclusively on three prey fish (coregonids, shad and roach) whilst the diet of littoral catfish was more variable, and was dominated by crayfish, perch, and roach. These results highlighted for the first time the interaction of larger catfish with the lake's pelagic food web, and thus possible consequences are discussed, including the potential contrasting role S. glanis may have for the lake's fishery.
\end{abstract}

Keywords: Trophic ecology, ecological plasticity, European catfish, pelagic habitat, littoral habitat, commercial fishermen, stomach content analyses, commercial harvest

\section{Introduction}

Invasive alien species (IAS) are nowadays recognized as a major component of global decline in biodiversity. Great efforts have been spent to find general patterns able to predict invasiveness, introduction paths and impacts [e.g., 1-6] with the aim to better allocate resources towards the management of the most problematic IAS [7]. Nevertheless, impacts of biological invasions are highly context dependent (e.g., [8-10]), triggering the predictions of the consequences of successful invasions [11]. This may be particularly true when the invader colonizes habitat that are different than those that are usually occupied both in the native and invaded ranges (i.e., are novel habitats). As such, studies aimed to gain ecological information of invasive population in novel environments are of great value to create data on which theoretical frameworks and hypotheses may then be developed and tested [8] to extend our understanding of IAS impacts and planning their management.

An example of successful invader in freshwaters able to establish into novel habitat types is represented by the European catfish Silurus glanis L., a large-bodied fish naturally distributed in large freshwater ecosystems of eastern Europe and western Asia [12]. Thanks to its fast growth and the large body size reached, S. glanis is highly appreciated among anglers [13] and is an important resource in aquaculture [14] and this have led to its voluntary introduction into different areas, both within and outside Europe [12, 15]. In western and southern Europe, it has established self-sustained populations rising 
conservation concerns due to its top-predator position and opportunistic feeding behavior $[12,15]$. Although a relatively limited number of studies have addressed the impacts of European catfish within the receiving communities [16], there have been studies documenting extirpation or significant reduction of some indigenous fish species through predation [17-18] and potential alteration of energy fluxes between freshwater - marine or freshwater- terrestrial environments via predation of anadromous species [19] or terrestrial prey (e.g., pigeons; frogs, rodents; [15-16]), respectively. As a top-predator, concerns have arisen over the potential competition with other native top-predators such as pike Esox lucius L. [20]. However, the extreme trophic plasticity typical of the species seemed to prevent this $[15,20-21]$. Among other impacts associated with catfish invasion there is also the potential for the introduction of new pathogens (Reading et al., 2012; Rees, 2020).

The ability of $S$. glanis to colonize non-native ecosystems seems to be driven by its trophic plasticity [20-21, 24]. European catfish is a top-predator but compared to others piscivorous fishes, it has a wider trophic niche [20-21, 25] and its diet is unpredictable, especially in the invaded range where the species adapt its diet to novel and available resources. For example, it has developed a new feeding behavior (i.e., "beaching behavior" [24]) to prey upon semiaquatic or terrestrial organisms or it tends to feed upon others exotic species such as the invasive shrimp Dikerogammarus villosus (Sowinsky, 1894) or the invasive red swamp crayfish Procambarus clarkii Girard, 1852 [25-26]. Moreover, the diet of invasive catfish populations can vary from the earliest to the latest stages of the invasion [16] and with seasons [27]. Catfish diet may be dominated by cyprinid fishes in the early stages of the invasion [16] or in winter and autumn [27] whilst crayfishes and other macroinvertebrates may dominate $S$. glanis' diet in the latest stages of the invasion or during spring and summer [16, 27]. Information, however, are particularly scarce for winter season when the species is considered least active [15]. Trophic ecology of S. glanis is thus variable in its invasive range with information mainly limited to riverine or reservoir populations where the fish is more easily captured [12] and to seasons of higher activity (i.e., spring and summer). Furthermore, little is known on the trophic ecology of the European catfish in oligotrophic and deep lakes.

In Italy, European catfish was first detected in 1937 in the Adda River [28] but the event was considered occasional and probably related to a stocking event [28], with no following reports. It was in the second part of the 1970s that the first established S. glanis population was reported in the Po River where the species was likely introduced in the 1950s [29]. Its introduction occurred mainly via stocking, often in put and take lakes, to enhance fishery for recreational angling $[15,17,30]$ or in some cases (e.g., Isonzo River) as a biocontrol agent to control other invasive species [31]. The species has now spread in all the major basins of northern and central Italy and in some large rivers of southern Italy (i.e., Aterno-Pescara and Volturno catchments; Supplementary Figure S1), where it has flourished in many environments, typically represented by eutrophic, turbid and still waters of canals, shallow lakes, and large rivers [17, 25] also taking advantage of degraded environment [32] and of climate change [33]. The remarkably ecological plasticity of European catfish is demonstrated by its ability to successfully colonize also deep and oligotrophic Italian subalpine lakes such as L. Maggiore [34].

Since oligotrophic deep lakes constitute a novel environment for S. glanis, then there remain many knowledge gaps on the ecology and potential impacts of the species in these ecosystems, especially in Italy [35]. To start to fill these gaps, we explored the diet of the species captured by commercial fishermen during late autumn/early winter period at three sites and two environments (littoral and pelagic) of Lake Maggiore. Interestingly, despite its benthic morphology, fishermen are increasingly reporting catches of S. glanis in the pelagic zone of the lake, especially in late autumn and winter, with these raising questions over the reasons of its presence in this compartment of the lake and the possible impacts on the pelagic food web. We analyzed the catfish harvest variation at the three sites and between habitat and we tested for differences in diet composition, prey abundance, estimated biomass and size of the preys among sites and environments. Due to the important role of L. Maggiore in providing fish for commercial purposes, to provide 
preliminary qualitative data on the role of $S$. glanis for this valuable service, changes in fish harvest since the introduction of catfish in L. Maggiore (1990; [36]) were analyzed and discussed. Finally, this work has seen the active contribution of professional fishermen who captured the fish and recorded stomach content data, it contributes to demonstrate the remarkable importance of anglers' collaboration in monitoring invasive fish species and their impacts in large lakes.

\section{Materials and Methods}

\subsection{Study site}

Lake Maggiore is the second largest and deepest lake in Italy after L. Garda and L. Como respectively. It has a surface of $212 \mathrm{~km}^{2}$, a maximum depth of $376 \mathrm{~m}$ and a mean depth of $176.5 \mathrm{~m}$. It is located in north-west Italy, south to the Alps and comprised into the Po River basin [37]. It is an oligomictic and oligotrophic lake, which together with others deep subalpine lakes (Como, Garda, Iseo and Lugano) account for the $80 \%$ of the Italian freshwater reservoirs [34]. Being in the most densely populated area of Italy, L. Maggiore has suffered severe impacts deriving from anthropogenic activities [37-38]. It underwent cultural eutrophication, reaching the maximum nutrients load in the 1970s, with natural oligotrophic conditions re-stablished in the 1990s [39]. L. Maggiore has also faced serious chemical pollution due to the presence of different classes of contaminants [40-44]. On top of these environmental issues, the introduction of non-native fauna has deeply altered the pristine community of the lake to the point that fish catches are now dominated by non-native species [34].

Lake Maggiore fish community is constituted of about 20 native species, but the introduction of several exotic fish species has substantially changed the lake's fish species richness and composition. Introductions occurred mainly intentionally to enhance commercial and recreational fisheries with European and north American species, reaching a total of at least 13 recognized non-native taxa [34]. Seven of these species has been introduced and established before 1960 such as at least two species of coregonids (now recognized both as hybrid of several Coregonus species native to different Swiss lakes [45-46], locally called "lavarello" and "bondella" and here after referred as Coregonus sp.), Alpine charr Salvelinus umbla (L.), rainbow trout Oncorhynchus mykiss (Walbaum 1792), largemouth bass Micropterus salmoides (Lacepède 1802), pumpkinseed Lepomis gibbosus (L.) and black bullhead Ameiurus melas (Rafinesque 1820). Additionally, six species have been introduced after 1960 and mostly became abundant during the 1990s, including roach Rutilus rutilus L., crucian carp Carassius carassius L., bitterling Rhodeus amarus (Bloch 1782), pikeperch Sander lucioperca (L.), ruffe Gymnocephalus cernua (L.), and European catfish.

Data from standardized fish community sampling of Lake Maggiore carried out in summer showed that non-native species of recent introduction (i.e., introduced after 1960) dominate the littoral zone of the lake whilst pelagic compartment is dominated by nonnative species introduced before 1960, particularly coregonids [47]. In the littoral compartment, fish biomass decreases with depth and is the highest within the first 6 meters and is dominated both as biomass and abundance by the omnivorous roach and perch Perca fluviatilis L. [47]. In contrast, in the pelagic zone the highest fish biomass is recorded between 30 - 40 meters depth [47] and planktivorous species are predominant. Among toppredators, only southern pike Esox cisalpinus Bianco \& Delmastro, 2011 and lake trout Salmo spp. are native, and they occur as rare species mainly in the littoral and pelagic zones, respectively [34, 38]. Other than European catfish, another non-native top-predator present is pikeperch [48], which occurs both in the littoral and in the pelagic zones [47].

\subsection{Fishing locations and gears}


Fishing was carried out at three sites located in the central/southern part of Lake Maggiore (Figure 1a). At each site, fishermen set benthic (60 mm mesh size, $500 \mathrm{~m}$ length and $5 \mathrm{~m}$ height) and pelagic gill nets $(80 \mathrm{~mm}$ mesh size, $750 \mathrm{~m}$ length and $10 \mathrm{~m}$ height $)$ at depths 15 to $35 \mathrm{~m}$ and 15 to $40 \mathrm{~m}$, for the littoral and pelagic zone, respectively (Figure 1b). Nets were set at dusk and withdrawn the following morning. Sampling activity for the study purpose was done in late autumn/early winter, from November 2019 to January 2020.
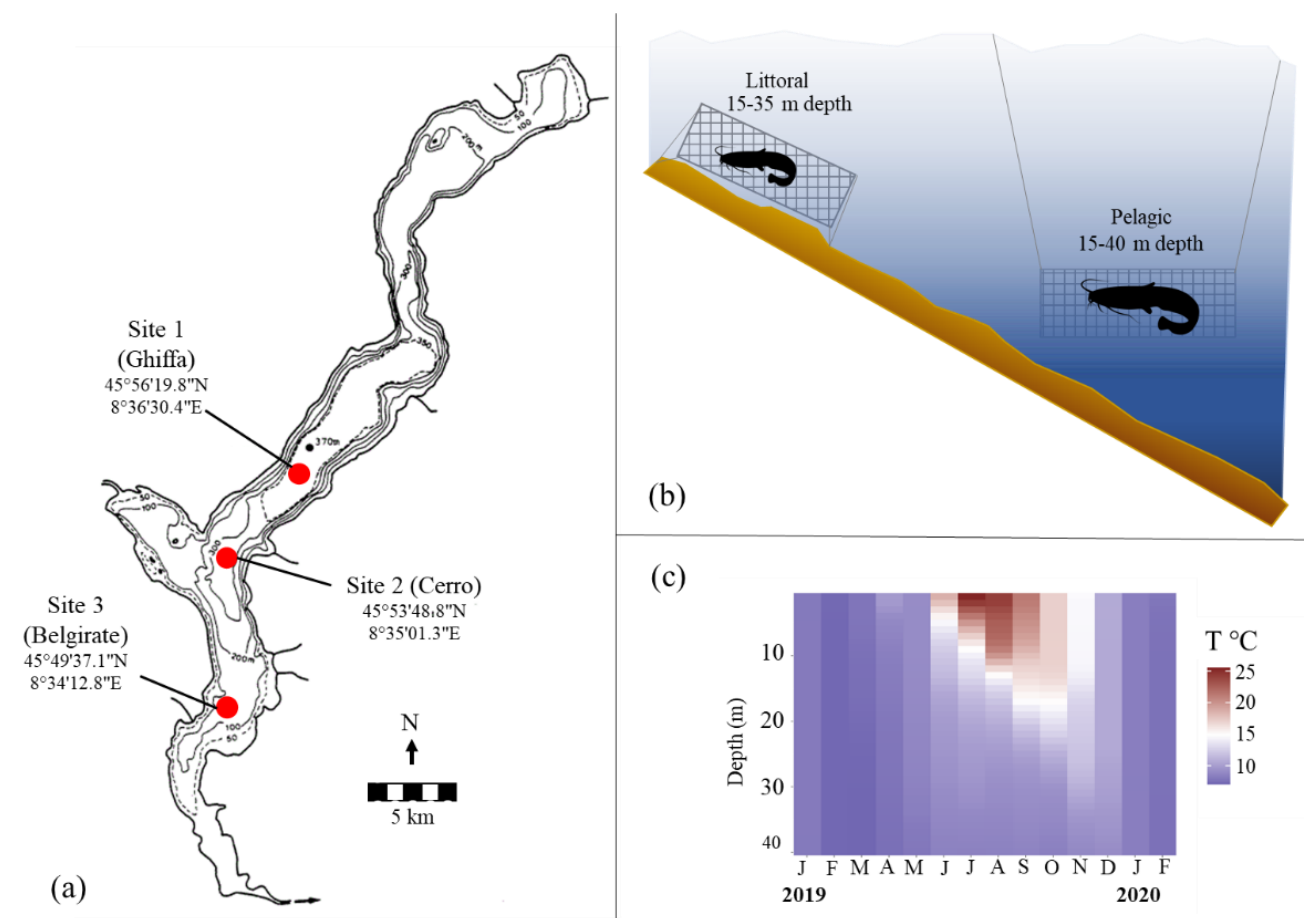

(c)

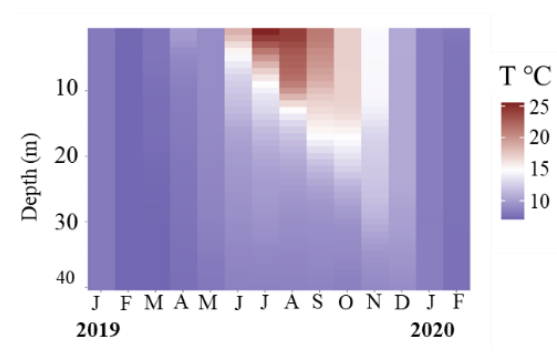

Figure 1 (a) Bathymetric map of Lake Maggiore (retrieved from https://wldb.ilec.or.jp/Search/listdata) and location of sampling sites with (b) schematic representation of the location of pelagic and littoral gillnets and (c) heatmap of temperature with depth measured for each month from January 2019 to February 2020 at the deepest point of the Lake (Ghiffa station, site 1).

\subsection{Stomach content and prey detection}

Fish were eviscerated as soon as the commercial fishermen reached his own laboratory. Stomachs were opened and prey items were recognized up to species level, counted and tape measured for they total length $(1 \mathrm{~cm})$. Prey that were not possible to recognize were discarded and were not processed further and empty stomachs were recorded. Data were registered day by day and were sent to CNR at the end of January 2020. The correct identification of food items was double checked by the authors analyzing independently a subsample of 10 full stomachs per fisherman and testing the coincidence in prey determination with that given by the individual fisherman.

\subsection{Data analyses}

Since distribution and feeding activity of catfish may have been influenced by water temperature, temperature distribution along the water column in 2019 and January-February 2020 were obtained from the deepest point of the lake (Ghiffa station; Figure 1a) as made available by the International Commission for the Protection of Italian-Swiss waters (CIPAIS). Data were collected with a Idronaut CDC304 temperature probe, with data registered across multiple depths, with a speed of $1 \mathrm{~m} / \mathrm{s}$ and a frequency of 200 milliseconds. Depth was obtained from hydrostatic pressure and data were then interpolated for each meter depth using Idronaut REDAS5 software (Idronaut Srl). 
Length of both catfish and their prey were used to back-calculate weight using length-weight relations (LWRs) obtained from an internal database of LWRs in different Italian lakes for fish (see supplementary material Table S2 for LWR parameters calculated for each species) while for crayfish, LWRs available in literature were used [49-50]. This enabled to estimate the biomass of catfish and their prey at each site and within each habitat.

Biomass (grams; BPUE) and number (individuals; NPUE) per unit effort $\left(\mathrm{m}^{2}\right)$ of catfish were calculated at each site and for each habitat (pelagic and littoral) and month and a multifactorial ANOVA followed by Tukey post doc test was used to test for differences in total length according to sampling site, month of capture and habitat.

For stomach content analysis, catfish were divided in two size classes (Class I: $\leq 100$ $\mathrm{cm}$; Class II $\geq 101 \mathrm{~cm}$ ) following previous work on catfish diet [24]. To compare feeding intensity and amount of food ingested by catfish of different size class and caught at different site and habitat, the vacuity index $\left(\mathrm{V}_{\mathrm{I}}\right)$ and fullness index $\left(\mathrm{F}_{\mathrm{I}}\right)$ were calculated where: $V_{I}$ is the proportion of empty stomach found with respect to the number of stomachs with contents and is expressed as a percentage [51]; $\mathrm{F}_{\mathrm{I}}$ is the percentual ratio between the total weight of a certain prey and the total weight of the predator [52]. Multifactorial ANOVA was then applied to test for possible influences of fish size, site, and habitat on these dietary metrics and on the amount and biomass of food ingested.

To assess the diet composition variation between habitat and size classes, the following three common metrics were calculated. The first was the frequency of occurrence $(\mathrm{FO} \%)$, which describes the proportion of non-empty stomachs in which a certain prey is found compared to the total of analyzed stomachs. The other two metrics were the numerical frequency $(\mathrm{N} \%)$ and the biomass contribution of prey $(\mathrm{W} \%)$, which are calculated as the proportional contribution in number/weight over the total number/weight recorded, respectively [53].

The numerical proportion of a given prey with respect to the total number of prey found in a single individual was calculated for each catfish and following an arcsin square root transformation, was used to build a Bray-Curtis distance matrix which served as input to the non-metric multidimensional scaling (nMDS). This ordination method was used to visualize variations in the core dietary niches (as 40\% standard ellipse areas; [54]) of catfish caught at different sites and habitats and belonging to different size classes. Three-way PERMANOVA was then used to test whether diet composition significantly differed between sites, habitat, and size classes with statistical significance evaluated after 9999 permutations.

Finally, feeding strategy of catfish of different habitat was investigate using the Costello modified plot [55-56]. In this graphical interpretation, frequency of occurrence is plotted against prey-specific abundances, which is calculated as the proportion between the numerical abundance of a certain prey over the total number of prey found in those stomach comprising that specific prey [56]. This method allows to visualize whether the diet of a predator is composed by dominant or rare species and thus if the predator is a generalist or a specialist and it can also help to distinguish between inter vs. intra individual's contribution to the trophic niche width.

All statistical analyses were performed in R [57] and used as significant threshold $p$ $<0.05$. nMDS and PERMANOVA were performed using the community ecology R package "vegan" [58].

\subsection{Additional information: L. Maggiore's fish commercial harvest}

Species-specific data of the fish commercial harvest since the introduction of catfish in L. Maggiore (1990; [36]) were provided by the Italian Swiss committee for fisheries (CISPP) and analyzed to assess the potential role of catfish on the lake's fishery.

\section{Results}

3.1. Temperature-depth profile in 2019 and winter 2020 
Temperature-depth profile showed as in June to November 2019 there was a considerable stratification with water temperatures $>15^{\circ}$ (and up to $25^{\circ} \mathrm{C}$ in July) within the first 5 (June) to $20 \mathrm{~m}$ (October) depths (Figure $1 \mathrm{c}$ ). Considering the three months of the study, November was the warmest and still showed a subtle stratification with temperatures around $15^{\circ} \mathrm{C}$ within the first 10 meters depth, progressively decreasing down to $9^{\circ} \mathrm{C}$ at $40 \mathrm{~m}$ depth. By December temperature decreased to $<10{ }^{\circ} \mathrm{C}$, with no stratification apparent (less than $1^{\circ} \mathrm{C}$ of difference between the temperature at the surface and at $40 \mathrm{~m}$ ) in both December and January (Figure $1 \mathrm{c}$ ).

\subsection{Catfish harvest in late autumn/early winter 2019/2020 at three sampling sites}

A total of 236 catfish were caught from the three localities, 101 in the sublittoral zone and 135 in the pelagic zone (Table 1). Fish ranged in total length between $67 \mathrm{~cm}$ and 150 $\mathrm{cm}$ and in estimated weight between 1932 and $22940 \mathrm{~g}$, with the largest fish found in the pelagic habitats and the smallest in the littoral one (Table 1).

Table 1. Number (NPUE), biomass (BPUE), total length (TL in centimeters) with min-max values and estimated weight (W in grams) with min-max values of European catfish harvested at each sampling site between the pelagic and littoral compartments. NPUE = number per unit effort (individual $\left./ \mathrm{m}^{2}\right)$; BPUE = biomass per unit effort (grams $/ \mathrm{m}^{2}$ )

\begin{tabular}{|c|c|c|c|c|c|c|}
\hline \multirow{2}{*}{$\begin{array}{c}\text { Site } \\
\text { Habitat }\end{array}$} & \multicolumn{2}{|c|}{1} & \multicolumn{2}{|c|}{2} & \multicolumn{2}{|c|}{3} \\
\hline & Pelagic & Littoral & Pelagic & Littoral & Pelagic & Littoral \\
\hline $\mathrm{N}$ & 58 & 41 & 65 & 32 & 12 & 28 \\
\hline \multirow{2}{*}{$\mathrm{TL}(\mathrm{cm})$} & 115.7 & 93.4 & 106.1 & 97.5 & 125.3 & 97.8 \\
\hline & $(89-150)$ & $(68-122)$ & $(87-145)$ & $(67-125)$ & $(99-140)$ & $(79-119)$ \\
\hline \multirow{2}{*}{ W (g) } & 10861.4 & 5623.9 & 8421.3 & 6617.9 & 13612.5 & 6346.1 \\
\hline & $(4619.8-22940.4)$ & $(2022.1-12165.4)$ & $(4308.5-20672.8)$ & $(1932.2-13107.3)$ & $(6406.2-18561.5)$ & $(3204.2-11270.1)$ \\
\hline NPUE & 0.008 & 0.016 & 0.009 & 0.013 & 0.002 & 0.011 \\
\hline BPUE & 113.9 & 95.9 & 73.0 & 120.2 & 21.8 & 177.0 \\
\hline
\end{tabular}

Catfish total length varied significantly across habitats, sites, and months of capture (Habitat ${ }^{*}$ Site ${ }^{*}$ Month: $F_{1,218}=3.7, p=0.006$ ), with post doc test revealing these differences were mainly between littoral and pelagic habitats among and within all sites and months ( $\mathrm{p}$ adjusted $<0.05$; Figure 2). This, however, was not observed at site 2 where pelagic catfish were significantly smaller than pelagic catfish caught at the other sites, particularly
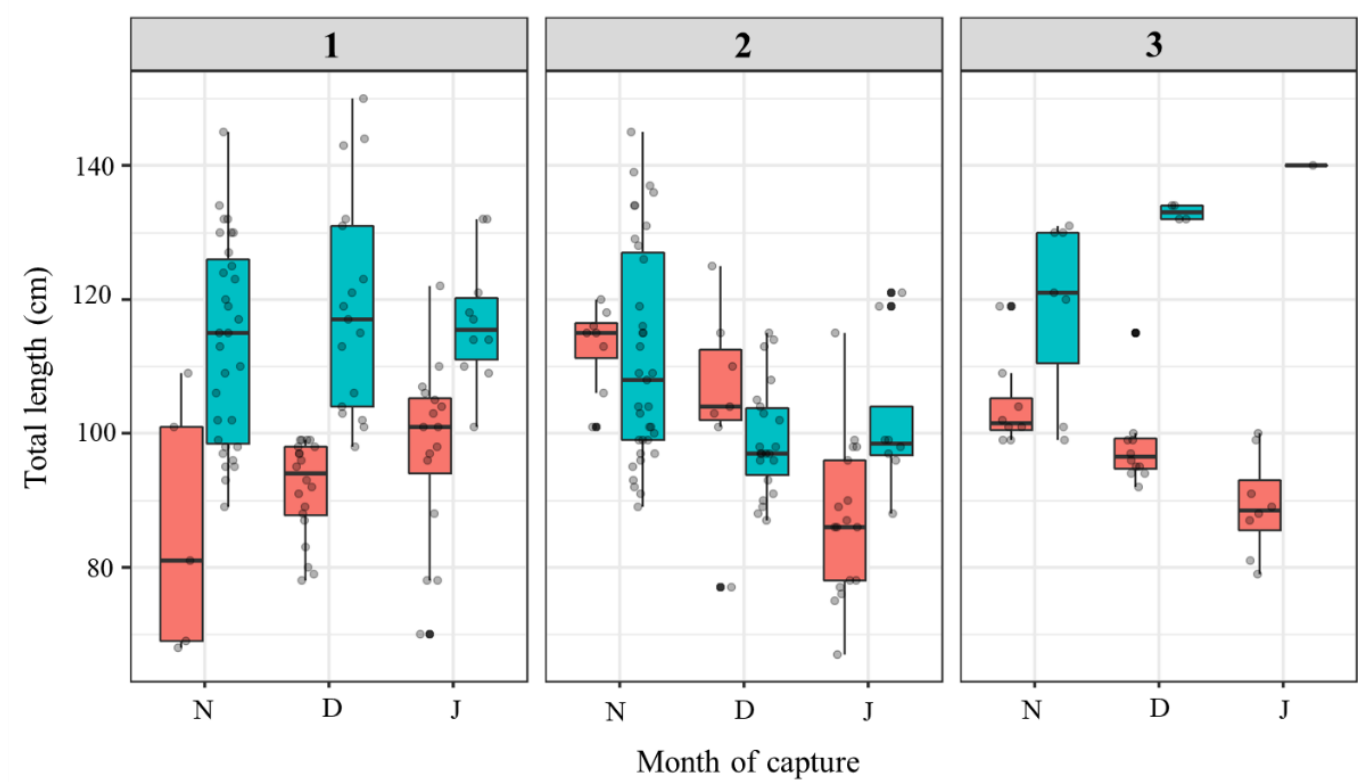

Littoral

Pelagic 
in December and January (Figure 2), but did not significantly differ in TL from the littoral catfish caught at the same site.

Figure 2. Box and whiskers plot of catfish total lengths across sampling month and between pelagic and littoral habitat at each sampling site.

Biomass (BPUE) and number (NPUE) of catfish varied between sites, habitats, and month of capture as well. However, it was possible to recognise some general patterns such as generally lower NPUE and BPUE in pelagic than littoral habitats, except at site 1 (Table 1; Figure 3) and a substantial decrease of both pelagic catfish NPUE and BPUE in December and January while both increased in most cases for littoral catfish (Figure 3). 

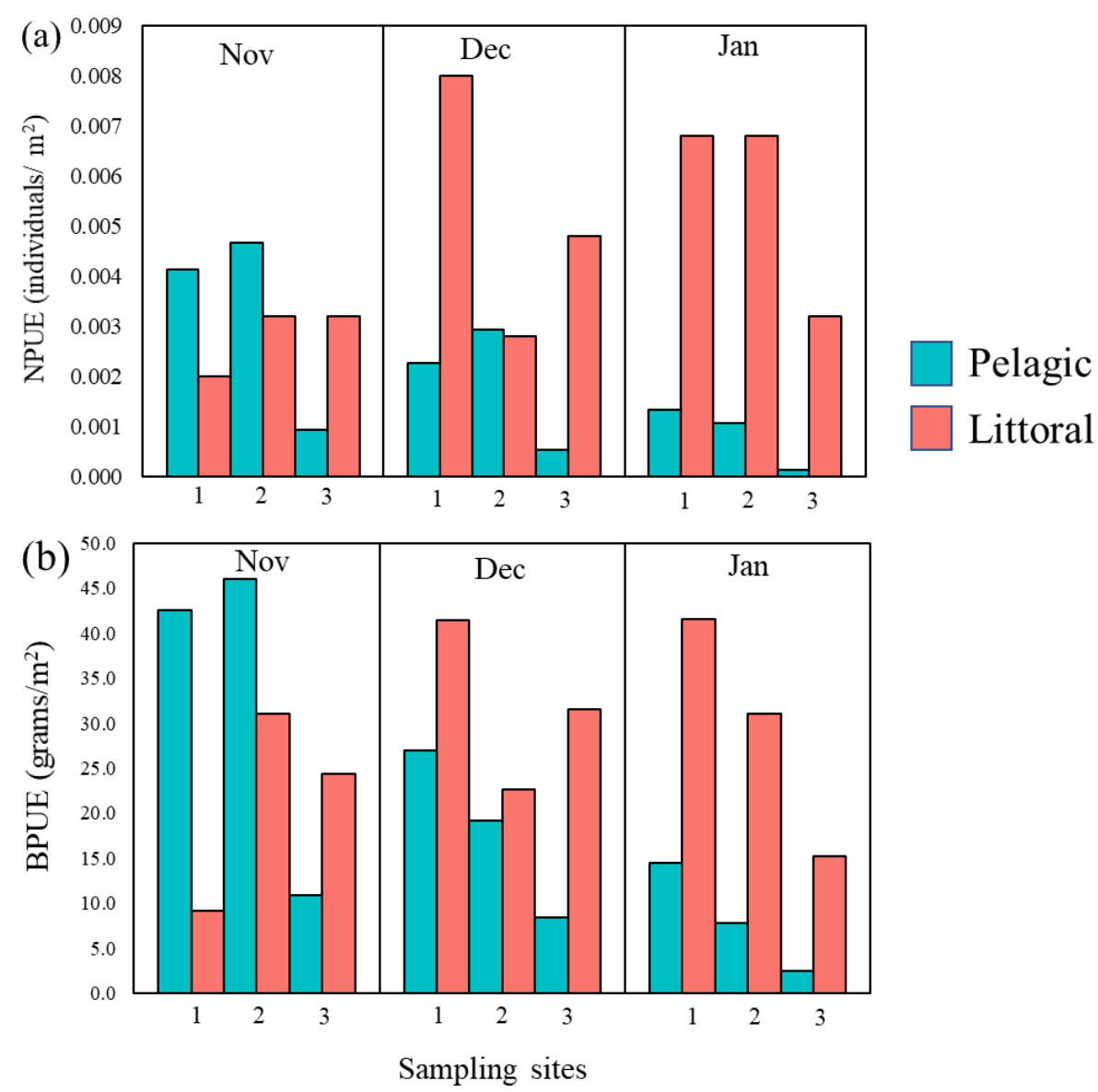

Figure 3. Distribution of (a) Numeric (NPUE) and (b) biomass (BPUE) of catfish across site and divided per habitat type (bars colour) and each month of capture.

\subsection{Catfish diet composition in pelagic and littoral habitats}

Of the 236 harvested catfish, $54\left(\mathrm{~V}_{\mathrm{I}}=22.8 \%\right)$ had their stomach empty and were thus discarded from further analyses. All the other fish had at least one identifiable food item in their stomach and were then considered in the analyses. Overall, a total of 581 prey items were counted having a total estimated weight of $63 \mathrm{~kg}$. The overall mean fulness index $\left(\mathrm{F}_{\mathrm{I}}\right)$ was of $4.63 \%$ with a minimum of $0.30 \%$ and a maximum of $35.0 \%$. $\mathrm{V}_{\mathrm{I}}, \mathrm{F}_{\mathrm{I}}$, weight and number of prey varied across sampling sites and month of captures, however the effect of these two variable was always negligible $(p>0.05)$ and therefore only comparisons between habitats and catfish size classes are presented (see supplementary material Table S3 for detailed dietary metrics for each habitat within each sampling site per month). VI was the lowest for Class I catfish caught in the littoral zone and the highest for Class 2 pelagic catfish (Table 2). $\mathrm{F}_{\mathrm{I}}$ was significantly lower in pelagic habitat $\left(\mathrm{F}_{1,178}=\right.$ $11.48, \mathrm{p}<0.001$ ) but did not vary significantly between size classes both between (size class $p=0.37$ ) and within (habitat ${ }^{*}$ size class $p=0.67$ ) habitats. Similarly, the average number of prey consumed by catfish was lower in pelagic than in littoral habitats $\left(\mathrm{F}_{1,178}=\right.$ 9.06, $\mathrm{p}=0.002)$ with no differences according to catfish size $(\mathrm{p}=0.51)$ and habitat ${ }^{*}$ size class $(p=0.24)$. In contrast, biomass of prey was significantly influenced by size class ( $F_{1}$, $178=14.38, p=0.002$ ) and did not vary significantly between or within habitats (habitat $p$ $=0.83$ and habitat ${ }^{*}$ size class $p=0.86$ ), indicating as, on average, larger catfish consumed less, yet larger, prey than littoral catfish. 
Table 2. Feeding intensity (as Vacuity index, $\mathrm{V}_{\mathrm{I}} \%$ ) and amount of food ingested (as Fullness index, $\mathrm{F}_{\mathrm{I}} \%$ ) together with number and biomass of prey of the two size classes (Class I $\leq 100 \mathrm{~cm}$ and Class II $\geq 101 \mathrm{~cm}$ ) of catfish caught in littoral and pelagic habitat of L. Maggiore.

\begin{tabular}{ccccc}
\hline Habitat & \multicolumn{2}{c}{ Littoral } & \multicolumn{2}{c}{ Pelagic } \\
Size class & Class I & Class II & Class I & Class II \\
\hline Nstomach & 53 & 26 & 31 & 72 \\
VI (\%) & 20.9 & 23.5 & 27.9 & 21.7 \\
Mean FI (\%) $\pm 95 \%$ CI & $5.81 \pm 1.55$ & $5.56 \pm 1.46$ & $4.32 \pm 0.94$ & $3.53 \pm 0.61$ \\
Total Nprey & 220 & 86 & 79 & 196 \\
Mean N prey & $4.15 \pm 1.11$ & $3.31 \pm 0.99$ & $2.55 \pm 0.57$ & $2.72 \pm 0.40$ \\
Total W (kg) & 11.8 & 15.3 & 7.62 & 28.6 \\
Mean W (g) $\pm 95 \%$ CI & $289 \pm 78.9$ & $454.7 \pm 108.6$ & $245.8 \pm 57.1$ & $397.3 \pm 64$ \\
\hline
\end{tabular}

Prey consumed belonged at 12 different species, two of which were exotic crayfish (Table 3). The remaining prey were fishes, with four of these being non-native species and comprising also others S. glanis (Table 3). The most frequent and abundant (both in terms of number and biomass) prey were coregonids Coregonus sp. followed by the land-locked shad Alosa agone (Scopoli, 1786) and the spiny-cheek crayfish Faxonius (formerly Onconectes) limosus (Rafinesque, 1817) (Table 3), with perch $P$. fluviatilis and roach $R$. rutilus also quite frequent and abundant while the remaining species occurred only occasionally ( $\% \mathrm{FO}<3.8 \%$; Table 3$)$ and were less abundant $(\% \mathrm{~N}<1 \% ; \% \mathrm{~W}<8.5 \%$; Table 3). When considering these metrics per habitat type, a considerable difference was apparent with only three prey species recorded in pelagic catfish, one of which (A. agone) exclusively detected in these catfish (Table 3 ). Only two species were shared in both habitats, namely Coregonus sp. and R. rutilus, but with the first being predominant in the diet of pelagic catfish and the second in the diet of littoral catfish (Table 3). While the diet of pelagic catfish was also dominated by a high numeric and biomass abundance of $A$. agone, the diet of littoral catfish was dominated by a high number and frequency of $F$. limosus, $P$. fluviatilis and R. rutilus. In term of biomass, the diet of littoral catfish was more variable than that of the pelagic ones, with for example conspecific prey having a high contribution ( $\% \mathrm{~W}=19 \%$; Table 3 ) despite being least abundant in terms of number (\%N $=2.3 \%$. Subtle differences were instead apparent between size classes where only a remarkable high frequency and biomass contribution of cannibalism $(\% \mathrm{~F}=19 \%$ and $\% \mathrm{~W}$ $=33 \%$ ) in class II littoral catfish was noted (see supplementary material Table S4). 
Table 3. List of the 12 prey species composing catfish diet and relative frequency of occurrence (FO\%), numeric (N\%) and biomass $(\mathrm{W} \%)$ abundance in the total sample and for each habitat type. Native (N) vs. non-native (NN) status of species is also reported together with the total number (N), mean total length (TL) in centimetres with min-max values in brackets, mean estimated weight in grams with min-max values in brackets and total weight (Wtot) in kilograms for each prey found in the analysed fish.

Total Pelagic Littoral

\begin{tabular}{|c|c|c|c|c|c|c|c|c|c|c|c|c|c|c|}
\hline Species & Status & $\mathbf{N}$ & TL (cm) & W (g) & Wtot $(\mathrm{Kg})$ & FO $\%$ & $\mathrm{~N} \%$ & $\mathrm{~W} \%$ & FO $\%$ & $\mathrm{~N} \%$ & W\% & FO $\%$ & $\mathrm{~N} \%$ & W\% \\
\hline Coregonus sp. & $\mathrm{NN}$ & 156 & $26.1(15-45)$ & $169.5(23.9-789.2)$ & 26.45 & 40.7 & 26.9 & 42.0 & 62.1 & 49.1 & 65.7 & 12.7 & 6.9 & 10.0 \\
\hline Alosa agone & $\mathrm{N}$ & 125 & $21.9(15-31)$ & $86(26.2-242.7)$ & 10.75 & 25.3 & 21.5 & 17.1 & 44.7 & 45.5 & 30.2 & 0 & 0 & 0 \\
\hline Rutilus rutilus & $\mathrm{NN}$ & 67 & $18(13-31)$ & $79.9(13-373.2)$ & 5.35 & 18.7 & 11.5 & 8.5 & 6.8 & 5.5 & 4.5 & 32.9 & 17.0 & 13.8 \\
\hline Perca fluviatilis & $\mathrm{N}$ & 58 & $14.2(8-24)$ & $38.7(5.7-160.6)$ & 2.45 & 14.8 & 10.0 & 3.9 & 0 & 0 & 0 & 32.9 & 19.0 & 9.1 \\
\hline Sander lucioperca & $\mathrm{NN}$ & 6 & $34.8(25-45)$ & 428.5 (126.9-808.4) & 2.57 & 2.7 & 1.0 & 4.1 & 0 & 0 & 0 & 6.3 & 2.0 & 9.6 \\
\hline Scardinius hesperidicus & $\mathrm{N}$ & 6 & $26.3(23-31.4)$ & $296.3(202-412)$ & 1.78 & 2.2 & 1.0 & 2.8 & 0 & 0 & 0 & 5.1 & 2.0 & 6.6 \\
\hline Squalius squalus & $\mathrm{N}$ & 1 & 35 & 450 & 0.45 & 0.5 & 0.2 & 0.7 & 0 & 0 & 0 & 1.3 & 0.3 & 1.7 \\
\hline Silurus glanis & $\mathrm{NN}$ & 7 & $48.1(49-59)$ & $584.2(396.6-786.7)$ & 5.11 & 3.8 & 1.2 & 8.1 & 0 & 0 & 0 & 8.9 & 2.3 & 19.0 \\
\hline Cottus gobio & $\mathrm{N}$ & 2 & $10.5(9-12)$ & $11.9(7.6-16.1)$ & 0.02 & 0.5 & 0.3 & 0.0 & 0 & 0 & 0 & 1.3 & 0.7 & 0.1 \\
\hline Lota lota & $\mathrm{N}$ & 2 & $28.5(28-29)$ & $170.7(161.2-180.2)$ & 0.34 & 1.1 & 0.3 & 0.5 & 0 & 0 & 0 & 2.5 & 0.7 & 1.3 \\
\hline Faxonius limosus & $\mathrm{NN}$ & 148 & $8(5-13)$ & $52(25.5-93.5)$ & 7.7 & 24.2 & 25.5 & 12.2 & 0 & 0 & 0 & 55.7 & 48.4 & 28.6 \\
\hline Procambarus clarkii & $\mathrm{NN}$ & 3 & $13.6(13-14)$ & $60(50-65)$ & 0.18 & 1.1 & 0.5 & 0.3 & 0 & 0 & 0 & 2.5 & 1.0 & 0.7 \\
\hline
\end{tabular}

This have resulted in a substantial differentiation of diet between the two habitat types, which was clearly visible in the nMDS graphs (Figure 4 a and b ). Multifactorial PERMANOVA confirmed that, although site, month of capture and size class (and relative interactions) had a significant contribution to the observed variation in catfish diet, habitat type was the most informative variable $\left(R^{2}=0.25\right.$; Table 4$)$.
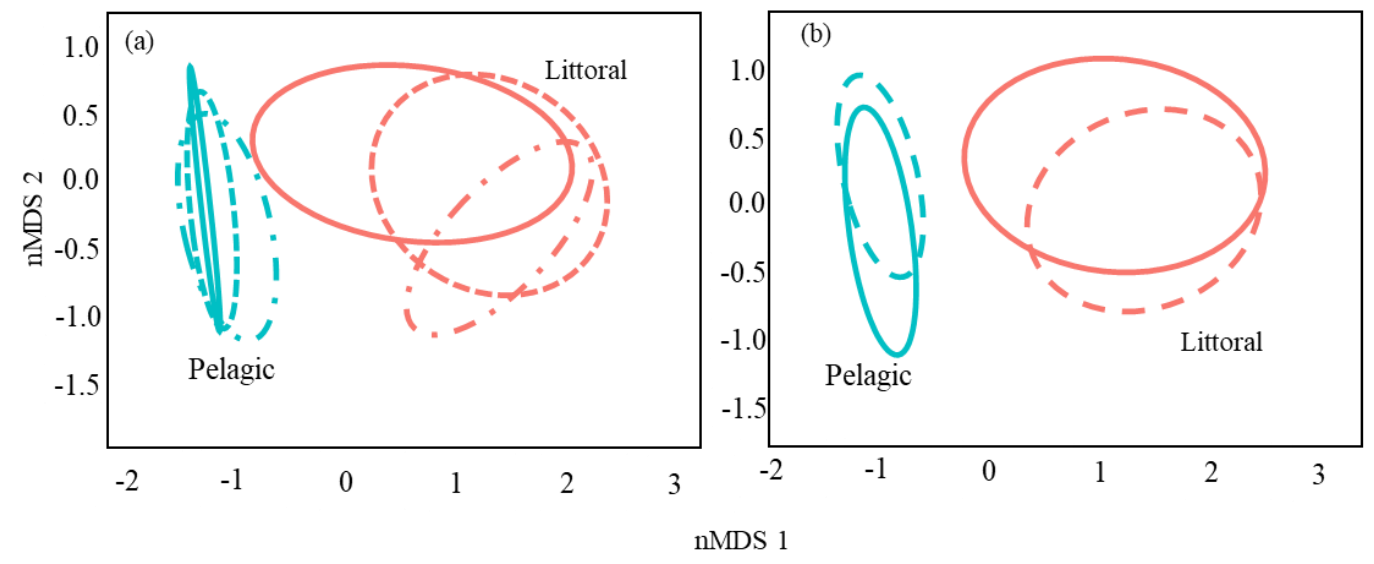

Figure 4. nMDS graphs built on arcisin square rooted numerical abundances and Bray Curtis dissimilarities matrix of the 12 prey species detected in the 182 analysed catfish stomachs displaying (a) dietary niches as $40 \%$ standard ellipse area per sampling site (dashed line $=$ site 1 ; dot-dashed line $=$ site 2 ; solid line $=$ site 3 ) and (b) dietary niches as $40 \%$ standard ellipse area per size class (solid line $=$ class $\mathrm{I} \leq 100 \mathrm{~cm}$ and dashed line $=$ Class $\geq 101 \mathrm{~cm})$. Stress was $=0.04$ indicating two dimensions ordination was sufficiently described. 
Table 4. PERMANOVA partition of the diet composition variation of the 182 analyzed catfish harvested in Lake Maggiore (12 prey species) based on arcsin square rooted numerical abundances and Bray-Curtis dissimilarities with p-value calculated after 9999 permutations.

\begin{tabular}{ccccccc}
\hline Source & $d f$ & $S S$ & MS & Pseudo F & $\mathbf{R}^{2}$ & $p$ \\
\hline Habitat & 1 & 16.02 & 16.02 & 75.65 & 0.25 & 0.0001 \\
Size class & 1 & 0.62 & 0.62 & 2.94 & 0.01 & 0.025 \\
Site & 2 & 1.40 & 0.70 & 3.31 & 0.02 & 0.002 \\
Month & 2 & 3.77 & 1.89 & 8.91 & 0.06 & 0.0001 \\
Habitat * Month & 2 & 2.30 & 1.15 & 5.45 & 0.04 & 0.0001 \\
Size class * Month & 2 & 0.90 & 0.45 & 2.13 & 0.01 & 0.04 \\
Site * Month & 4 & 1.78 & 0.45 & 2.10 & 0.03 & 0.01 \\
Habitat * Size class & 1 & 1.29 & 1.29 & 6.10 & 0.02 & 0.0006 \\
Habitat * Site & 2 & 0.38 & 0.19 & 0.73 & 0.006 & 0.49 \\
Size class * Site & 2 & 1.91 & 0.96 & 4.51 & 0.03 & 0.0002 \\
Habitat * Size class * Site & 2 & 0.67 & 0.34 & 1.58 & 0.01 & 0.12 \\
Habitat * Size class * Month & 2 & 1.15 & 0.57 & 2.70 & 0.02 & 0.009 \\
Habitat * Site * Month & 2 & 0.34 & 0.17 & 0.81 & 0.005 & 0.58 \\
Size class * Site * Month & 1 & 0.10 & 0.10 & 0.46 & 0.001 & 0.79 \\
Residuals & 170 & 32.83 & 0.22 & & 0.50 & \\
Total & 181 & 65.48 & & & 1.00 & \\
\hline
\end{tabular}

The differences in the diet composition were reflective of contrasting feeding strategies between pelagic and littoral catfish (Figure 5). Examining the feeding strategy plot in fact, it can be observed as the pelagic catfish were characterised by a high degree of population specialisation which suggest a restricted trophic niche. In contrast, the feeding strategy of littoral catfish appeared more mixed and suggest a wider trophic niche, with both between individual contribution (i.e., individual predators specialised on the consumption of some rare species such as Coregonus sp. and S. lucioperca) and a population specialisation on F. limosus (Figure 5).

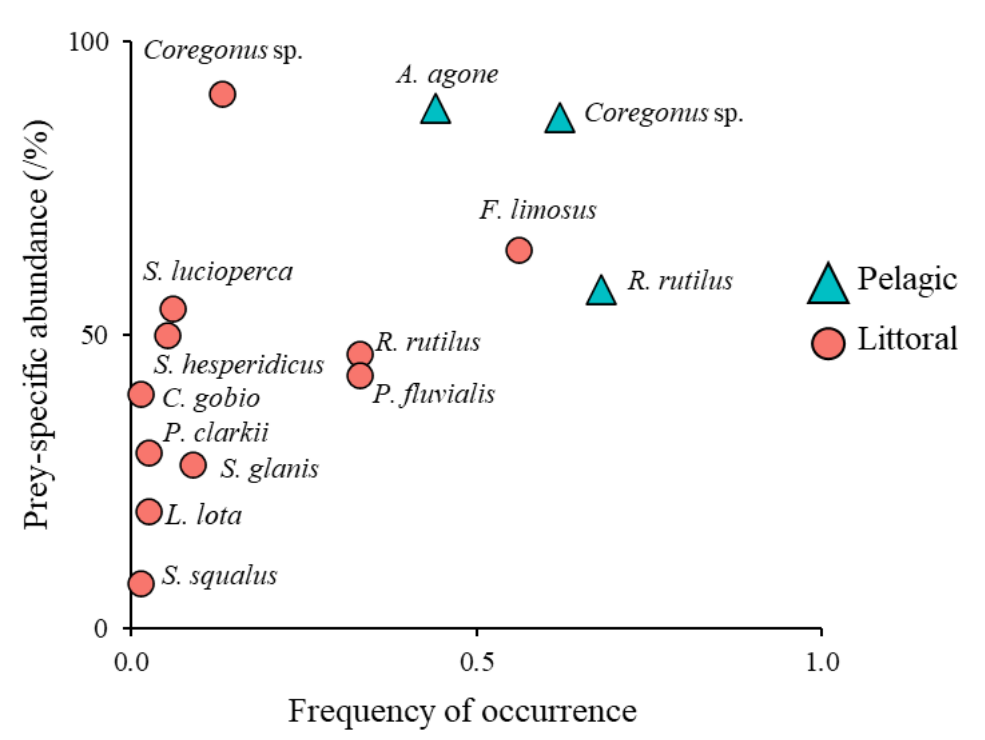

Figure 5. Feeding strategy plot (modified Costello graph; [55-56]) of pelagic and littoral catfish diet displaying frequency of occurrence and prey-specific abundance of each prey (circles = prey item of littoral catfish; triangles = prey items of pelagic catfish). 


\subsection{Trends in L. Maggiore's fishing harvest during the 20 years of catfish invasion}

Total commercial fishing harvest in L. Maggiore declined markedly between 1995 and 1999, reaching the lowest amount of total catch in 1998 (52 tons; Figure 6 a). Since the 2000s, catches increased again without anyway reaching the high level of harvest observed at the start of the 1990s (> 266 tons/year; Figure 6a). Across the 20 years examined, coregonids, shad and roach dominated the catches. Changes were observed also in the composition of the catches with coregonids dominating the catches until 1998 but then decreasing sharply between 1999 and 2004 when shad and coarse fish became dominant. Since 2005, coregonids catches started to increase again and kept dominating the harvest together with shad and roach (Figure 6 a).

Notably, although S. glanis was first detected in 1990, it started to be significantly targeted by commercial fishermen only since 2016. In only five years, the total annual harvest of catfish has quintuplicated being of 3.6 tons in 2016 and 19 tons in 2020 (Figure $6 \mathrm{a}$ and b). Similarly, the contribution of catfish to the total annual catch increased from the $3.2 \%-4.2 \%$ in $2016-2018$ to the $11.7 \%$ in 2019 and the $12.5 \%$ in 2020 .

Considering the total annual catches of predators only (Figure $6 \mathrm{~b}$ ), mostly the same trend of the total catch was observed except for the last four years where, the contribution of S. glanis marked a peak, particularly in 2019 and 2020 (Figure 6 b). As for the other predators, pike and trout were the only two predators dominating the commercial harvest until 1995. In 1996, pikeperch started to become targeted by commercial fishermen and its contribution has increased continuously since then. In contrast, trout and pike catches, after an initial decline, remained quite constant (Figure $6 \mathrm{~b}$ ).

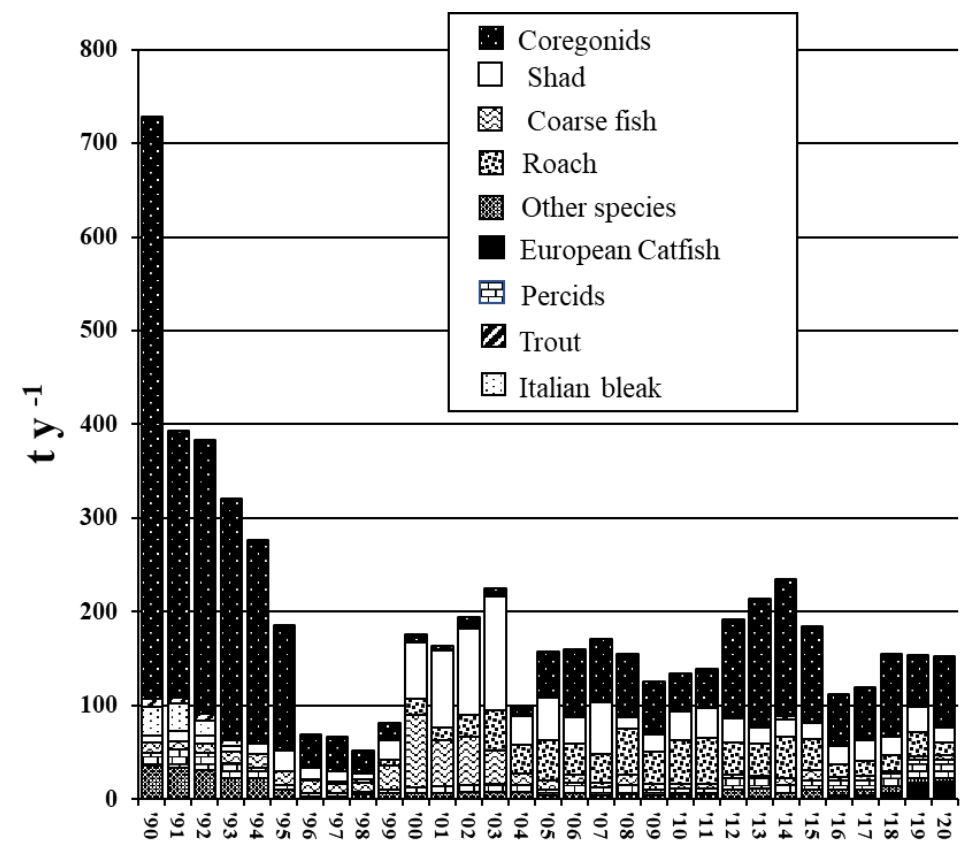

(a)

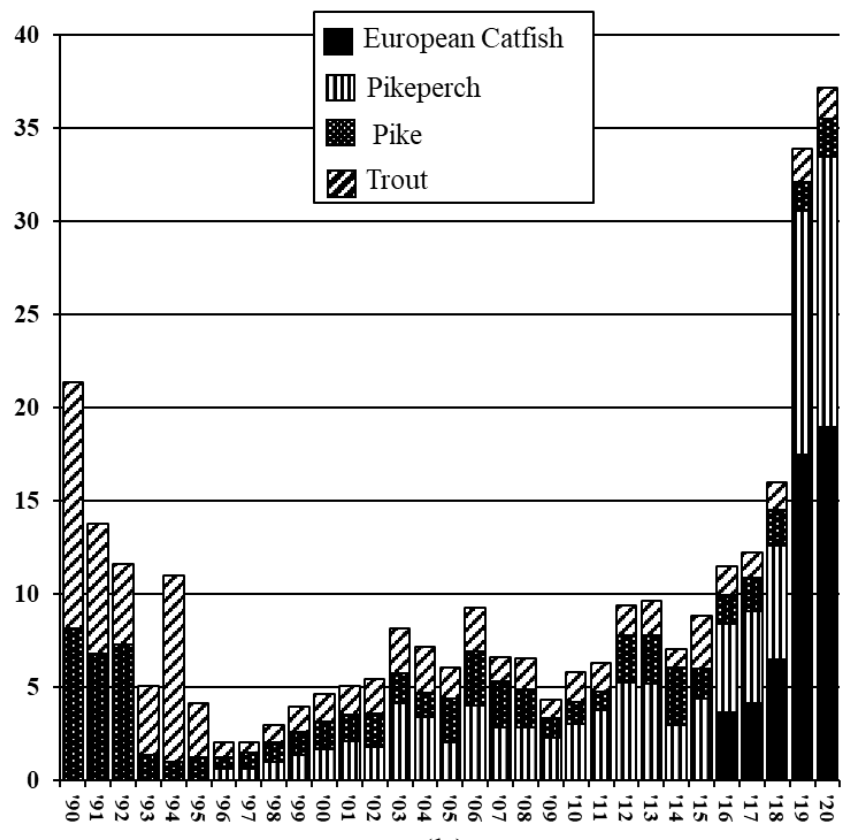

(b)

Figure 6. Species-specific (a) and predators only (b) fish harvest composition (tons/year) in L. Maggiore since the invasion of S. glanis (1990-2020) where Coregonids = "lavarello" and "bondella" Coregonus sp.; Percids = S. lucioperca, P. fluviatilis and G. cernua; Trout = Salmo spp.; Italian bleak = Alburnus alborella $($ Bonaparte, 1841) other species = S. umbla, L. lota, E. cisalpinus, Anguilla anguilla (L.), Tinca tinca (L.) and Cyprinus carpio L.

\section{Discussion}

Trophic ecology of S. glanis has been studied mostly in eutrophic lakes and reservoirs or large rivers and this is the first work addressing the diet of catfish in a deep oligotrophic and large lake such as L. Maggiore, particularly during winter when the species is thought to be least active [59-60]. Despite its bottom-dweller aspect, our data showed that catfish in L. Maggiore can utilise both pelagic and littoral habitats and rely, 
at least in the short term, on the distinct resources available in the two compartments. Moreover, largest catfish are more likely to migrate in pelagic habitats for feeding where their opportunistic top-predator behavior may alter ecological equilibria and associated ecosystem services.

In late autumn/early winter 2019, abundance and biomass of pelagic catfish was lower than that of littoral catfish (except at one site) and it was generally higher in November than in December and January. These results suggest that there is, potentially, a segregation in habitat occupation between size classes with larger individuals $(>100 \mathrm{~cm})$ prevailing in the open waters (pelagic habitats) and medium-sized ones $(<100 \mathrm{~cm})$ frequenting more evenly the littoral zone, but with a seasonality in this segregation. This is in agreement with previous studies on depth and temperature migrations of European catfish, which found that the species' movement varies with seasons $[32,61]$ and between juveniles and adults [59]. The higher abundance of catfish in the pelagic zone observed in November may be consistent with Capra et al. [32] reporting movements of catfish being frequent when temperature is comprised between 15 and $24^{\circ} \mathrm{C}$ while decreasing at lower temperatures. In the studied period, temperature data of the deepest point of the lake showed temperature in November 2019 was around $15^{\circ} \mathrm{C}$ within the first 10 meters (Figure $1 \mathrm{c}$ ), while it decreased to $<10^{\circ} \mathrm{C}$ along the entire water column in December and January. The dispersal of larger individuals into the pelagic zone found in this study, instead, is in contrast with previous studies in which smaller individuals were found to be more prone to disperse $[59,62]$. However, different factors may influence S. glanis movements [62], including social interactions with conspecific which were not considered in this study. Furthermore, this habitat segregation was not observed at all study sites and even where it was observed, some overlaps in total length between littoral and pelagic catfish were present and this highlights once more as catfish complex behavioural ecology needs to be further investigated, particularly in the invaded range [12].

The segregation into pelagic and littoral habitats were also reflected in the distinct diet and feeding strategy of catfish caught in the two compartments, investigated through stomach content analyses. Among different variable considered such as size class, site and month of capture, habitat type seemed to be the most explanatory variable. Although many studies reported difficulties to study European catfish diet through stomach content analyses due to high rate of stomach emptiness (e.g., [21, 25]) and despite considering the season of least activity of the species, the percentage of empty stomachs were lower than other studies and comparable to periods of high activity [20-21, 27,63] with also the fulness index, used as a proxy of fish activity, having similar ratio to that observed in the Arno River in spring [25]. Thus, even though there was likely an effect of temperature (considered as month of capture) on the dispersal of catfish, it did not affect the diet composition nor the feeding activity of the fish, at least in the study period. Diet is known to change with ontogeny in S. glanis, however we observed little variation in diet composition between size classes, with catfish body size influencing mainly the biomass $(\% \mathrm{~W})$ and therefore the size of the prey ingested, with larger individuals consuming larger prey, as observed elsewhere (e.g., [26]). Some differences were however apparent in the littoral catfish, with a decrease in the importance of F. limosus in Class II individuals joined with an increase in the frequency and biomass contribution of prey fish (i.e., pikeperch, rudd) and cannibalism, with this latter potentially indicating a paucity of resources available for Class II individuals in the littoral habitat [15]. However, the size of catfish analysed lacking smaller individuals (total lengths $<67 \mathrm{~cm}$ ) and the unbalanced sample number per size class in each habitat have probably prevented us to detect any significant effect of ontogeny on the diet. Therefore, habitat type emerged as the most important variable explaining the difference in the diet of pelagic vs. littoral catfish, with the diet of the former being constituted by only three items (coregonids, shad and roach), towards which the population has specialized. Littoral catfish had instead a more diverse diet, with 11 prey species detected although with a high degree of specialization towards the invasive crayfish F. limosus. As no measures of prey availability were done in this study, it was not possible to evaluate whether this specialization was a case of prey selection but, 
it is likely that catfish consumed, opportunistically, the most common prey. In fact, there is a good correspondence between the most abundant prey fish found in pelagic and littoral catfish with pelagic and littoral fish assemblages detected in a previous survey in Lake Maggiore [47]. Moreover, the invasive crayfish, which dominated the diet of littoral catfish, can have locally abundant population, contributing substantially to the diet of littoral fishes [64], besides being a staple prey of S. glanis also in its native range [65].

Considering that larger individuals were more likely to occur in the pelagic zone and that diet was composed by distinct resources than littoral catfish, then our results suggests that these catfish likely migrate into the pelagic zone to feed, at least in late autumn/early winter. European catfish movements are mainly associated to the search of prey and spawning or pre-spawning needs [61, 66-67]. As the spawning of S. glanis takes place in vegetated waters [68] and when temperature reaches 18-22 ${ }^{\circ} \mathrm{C}$ [69], then considering the temperature of the study period, spawning should have been in June and thus we can exclude the observed movement were associated to reproduction. The search of food is thus a plausible explanation of the movement of catfish into the pelagic compartment. This interpretation is also consistent with previous studies documenting through stable isotope analysis a resource use shift ( as primary production sources indicated by stable isotope ratio of carbon) in large-bodied catfish (e.g., [21, 23]). The reason of this behaviour may be a context-dependent answer of catfish to a higher prey availability in the pelagic compartment or it may be an adaptive behaviour that has contributed to the successful invasion of L. Maggiore. Due to the limited spatial (only 3 sites in the central part of the lake) and temporal ( 3 months) coverage of this study, it was not possible to speculate further on which of the two processes may have been involved but the study has settled the basis for future studies able to address this important question.

Another important finding that emerged in this study is the new predation pressure that $S$. glanis is posing, especially to the pelagic habitat of L. Maggiore. The native pelagic compartment of the lake, in fact, is poor of native predators, with large lake trout being the only native pelagic predators but migrating for reproduction in rivers at the beginning of autumn and pike being predominantly a littoral species. Top-predator's nature of $S$. glanis has often been questioned due to its high trophic plasticity [15-16, 70] but our data suggests that, in L. Maggiore, pelagic catfish are exploiting mainly planktivorous fish species (coregonids and shads) thus raising a new top-down pressure which may add to that of pikeperch and trout [71], especially on relatively large fish. Although in the native range, predation pressure of $S$. glanis is considered limited [72], and in most invaded areas the species feeds mainly on non-native species limiting its impact on native communities [15], the low abundance of native pelagic predators in L. Maggiore suggests that S. glanis has the potential to alter fish population dynamics and, potentially, cause consequent cascade effect on pelagic food webs that needs to be further investigated. To better quantify the ecological consequences of $S$. glanis invasion is thus necessary to extend the study of its trophic ecology to a wider spatial and temporal scale, potentially including also trophic interactions with the other top-predators and with measures of prey availability.

Besides the ecological impacts, the species may have impacts also on the lakes' ecosystem services such that deriving from professional fisheries. Our preliminary data on the role of catfish harvest on catches in the 20 years of S. glanis invasion showed as the species started to become a fishery target only recently (i.e., in the last five years). However, in a few years, the total catfish harvest has quintuplicated and so has been its proportional contribution to the total fish harvest (from $3.2 \%$ in 2016 to $12.5 \%$ in 2020), indicating that commercial fisheries may benefit from harvesting catfish. This is not surprising given that the importance of S. glanis for both recreational and professional angling is increasingly recognized [13] and that catfish populations in their native range can't reach carrying capacity due to high angling pressure [15, 35]. However, our data, showed that the fish harvest in Lake Maggiore is dominated by those species that were also most consumed by catfish like coregonids. Since catfish, is sold at a raw price 
considerably lower than coregonids ( 1 euro kg-1 vs. 6 euro kg-1) then these results highlight a possible contrasting role of catfish for professional angling in Lake Maggiore which should be investigated further through a more comprehensive and quantitative study on catfish trophic ecology and economic balances.

Commercial fisheries data must be interpretated with caution as they do not strictly reflect the natural variations in abundances and populations dynamics of fishes in the ecosystem. The trends of the commercial harvest observed in this study in fact, also reflected socio/political and economic events. For example, the decline in the total annual catches of coregonids between 1996-2004 is the consequence of fishing ban due to DDT pollution (e.g., [41, 73]) that led to the dramatic decrease of the number of professional fishermen [34]. The fact that catfish has started to be targeted in 2016 only may be itself a consequence of market interests rather than a proxy of its abundance. This has thus prevented us to make any further investigation on the impacts of catfish on the total harvest of fish in L. Maggiore. Nevertheless, these data are still of value as they provide in most cases the only long-term information available for fish populations in large ecosystems like L. Maggiore and in this work, have allowed to underline the contrasting role that $S$. glanis may have on fisheries, highlighting the need of further investigations for a better management of the lake's fishery.

Ecological and economic impacts of European catfish may be more intense in the future, due to global warming. One of the latest climatic predictions on Lake Maggiore basin [74], forecasted an increase of average air temperature from $1.7^{\circ}$ (best scenario) to $4^{\circ}$ $\mathrm{C}$ (worst scenario) by the end of the century. While the effect of rising air temperatures may be dampened with depth, there is evidence that in the first $70 \mathrm{~m}$ depth, water temperatures follow the trend of air temperatures, with a predicted warming up to $>3^{\circ}$ $C$ by 2085, with this being variable according to the considered scenario [75]. Warmer temperature may boost the invasion potential of alien species [11] by increasing their feeding, growth, and reproduction rates [76-77]. Signs of this have been already detected for some species in Lake Maggiore and adjacent lakes in the past three decades [36, 48, 78]. This may be particularly true for European catfish whose optimal growth temperature is comprised between $25-28^{\circ} \mathrm{C}$ [15] and whose highest feeding activity is meant to be at temperatures $>17^{\circ} \mathrm{C}$ [79]. Thus, at the actual temperature, optimal growth and foraging activity of $S$. glanis are likely to be restricted to the warmest season (July to October) but the rising of water temperatures may extend this period leading to a faster growth of the species and a potential higher foraging activity. Warming temperatures in L. Maggiore's basin may also allow the species to colonise habitats previously inaccessible due to low temperatures [33], such as some major tributaries of the lake (e.g., Toce River). Therefore, the quantification and monitoring of the impacts of predators such as European catfish is also fundamental in the view of global warming.

\section{Conclusions}

Thanks to the collaboration of commercial fisherman, this study has provided novel important information on the ecology of the invasive S. glanis in Lake Maggiore, highlighting how catfish of different size class can make a different use of the different habitats of the invaded ecosystem. Also, it underlines the new potential top-down pressure of the species especially on the pelagic food web and a possible contrasting role of the species for commercial fishery. Despite some biases may have influenced the results (e.g., catfish of smaller size lacking and potential missing information on stomach content data), the study has strongly benefited from the involvement of fishermen as citizen scientist without whom it would not have been possible to obtain such information due to logistic (i.e., difficulties in catching catfish in such a big ecosystem) constrains. This confirm once more as the involvement of fishermen, and citizen scientist in general, in biological invasions studies (e.g., [80-81]) is crucial and it has a double outcome: raising awareness about the impacts of fish introduction and, on the other side, extend scientific 
knowledge. In future, more fishermen should be involved to extend the spatial and temporal scale covered in this study.

Supplementary Materials: The following are available online at www.mdpi.com/xxx/s1, Figure S1: Distribution of S. glanis in the main Italian hydrological basins. Highlight in red where the species is established: $1=$ Po; 2 = Adige; 3 = Tagliamento; $4=$ Isonzo; $5=$ Sile; $6=$ Brenta; $7=$ Canalbianco; 8 = Serchio; 9 = Reno; $10=$ Arno; 11 = Ombrone; 12 = Tevere $; 13=$ Aterno-Pescara;14 =Volturno.; Table S1: Linear regressions parameters of length-weight relations (LWRs) of prey fish species calculated from an internal database of length and weight of fish species sampled in different Italian lakes from 2007 to 2014; Table S2: Feeding intensity (as Vacuity index, $V_{I} \%$ ) and amount of food ingested (as Fullness index, $F_{I} \%$ ) together with number and biomass of prey at each sampling site and for each of the two size classes (Class $I \leq 100 \mathrm{~cm}$ and Class II $\geq 101 \mathrm{~cm}$ ) per month of capture of catfish caught in littoral and pelagic habitats of L. Maggiore; Table S3: List of the 12 prey species composing catfish diet and relative frequency of occurrence (FO\%), numeric (N\%) and biomass (W\%) abundance for each catfish size class in each habitat.

Author Contributions: Conceptualization, P.V. and V.D.S.; methodology, P.V. and V.D.S; formal analysis, V.D.S.; resources, P.V. and V.D.S; data curation, V.D.S. and P.V.; writing-original draft preparation, V.D.S.; writing-review and editing, P.V.; supervision, P.V.; project administration, P.V.; funding acquisition, P.V. All authors have read and agreed to the published version of the manuscript

\section{Funding: V.D.S. and P.V. were supported by LIFE15 NAT/IT/000823 IdroLIFE Project.}

Data Availability Statement: data can be made available upon request from the corresponding author

Acknowledgments: We are particularly thankful to the professional fishermen who caught catfish and collected stomach content data for the dietary analyses. We wish also to thank the CIPAIS and the CISPP for providing water temperature and fish harvest data

Conflicts of Interest: The authors declare no conflict of interest.

\section{References}

1. Conser, C., Seebacher, L., Fujino, D. W., Reichard, S., DiTomaso, J. M. The development of a plant risk evaluation (PRE) tool for assessing the invasive potential of ornamental plants. PloS one 2015, 10, e0121053, https://doi.org/10.1371/journal.pone.0121053.

2. Copp, G. H., Vilizzi, L., Tidbury, H., Stebbing, P. D., Tarkan, A. S., Miossec, L., Goulletquer, P. Development of a generic decision-support tool for identifying potentially invasive aquatic taxa: AS-ISK. Manag. Biol. Invasions, 2016, 7, 343-350, https://doi.org/10.3391/mbi.2016.7.4.04.

3. Dick, J.T., Laverty, C., Lennon, J.J., Barrios-O'Neill, D., Mensink, P.J., Robert Britton, J., Médoc, V., Boets, P., Alexander, M.E., Taylor, N.G., Dunn, A.M., Hatcher, M.J., Rosewarne, P.J., Crookes, S., MacIsaac, H.J., Xu, M., Ricciardi, A., Wasserman, R.J., Ellender, B.R., Weyl, O.L., Lucy, F.E., Banks, P.B., Dodd, J.A., MacNeil, C., Penk, M.R., Aldridge, D.C. and Caffrey, J.M. Invader Relative Impact Potential: a new metric to understand and predict the ecological impacts of existing, emerging and future invasive alien species. J. Appl. Ecol., 2017, 54, 1259-1267, https://doi.org/10.1111/1365-2664.12849.

4. Matthews, J., Beringen, R., Creemers, R., Hollander, H. D., Kessel, N. V., Kleef, H. V., van de Koppel, S., Lemaire, A. J. J., Baudewijn, O., Verbrugge, L. N. H., Hendriks, A. J., Schipper, A. M., van der Velde, G., Leuven, R. S. E. W. A new approach to horizon-scanning: identifying potentially invasive alien species and their introduction pathways. Manag. Biol. Invasions, 2017, 8, 37-52, https://doi.org/10.3391/mbi.2017.8.1.04.

5. Britton, J. R., Gutmann Roberts, C., Amat Trigo, F., Nolan, E. T., De Santis, V. Predicting the ecological impacts of an alien invader: experimental approaches reveal the trophic consequences of competition. J. Anim. Ecol., 2019, 88, 1066-1078, https://doi.org/10.1111/1365-2656.12996.

6. Vilizzi, L., Copp, G. H., Hill, J. E., Adamovich, B. et al. A global-scale screening of non-native aquatic organisms to identify potentially invasive species under current and future climate conditions. Sci. Total Environ., 2021, 788, 147868, https://doi.org/10.1016/j.scitotenv.2021.147868.

7. Copp, G.H., Garthwaite, R., Gozlan, R.E. Risk identification and assessment of non-native freshwater fishes: a summary of concepts and perspectives on protocols for the UK. J. Appl. Ichthyol., 2005, 21, 371-373, https://doi.org/10.1111/j.14390426.2005.00692.x.

8. Ricciardi, A., Hoopes, M. F., Marchetti, M. P., Lockwood, J. L. Progress toward understanding the ecological impacts of nonnative species. Ecol. Monogr., 2013, 83, 263-282. https://doi.org/10.1890/13-0183.1 
9. Boets, P., Laverty, C., Fukuda, S., Verreycken, H., Green, K., Britton, R. J., Caffrey, J., Goethals, P. L. M., Pegg, J., Médoc, V., Dick, J. T. Intra-and intercontinental variation in the functional responses of a high impact alien invasive fish. Biol. Invasions, 2019, 21, 1751-1762, https://doi.org/10.1007/s10530-019-01932-y.

10. Grimm, J., Dick, J. T., Verreycken, H., Jeschke, J. M., Linzmaier, S., Ricciardi, A. Context-dependent differences in the functional responses of conspecific native and non-native crayfishes. NeoBiota, 2020, 54, 71-88, https://doi.org/10.3897/neobiota.54.38668.

11. Ricciardi, A., Iacarella, J. C., Aldridge, D. C., Blackburn, T. M., Carlton, J. T., Catfors, J. A., Dick, J. T. A., Hulme, P. E., Jeschke J. M., Liebhold A. M., Lockwood J. L., MacIsaac H. J., Meyerson L. A., Pyšek P., Richardson D. M., Ruiz G. M., Simberloff D., Vilà M., Wardle, D. A. Four priority areas to advance invasion science in the face of rapid environmental change. Environ. Rev., 2021, 29, 119-141, https://doi.org/10.1139/er-2020-0088.

12. Cucherousset, J., Horky, P., Slavík, O., Ovidio, M., Arlinghaus, R., Boulêtreau, S., Britton, R., García-Berthou, E., Santoul, F. Ecology, behaviour, and management of the European catfish. Rev. Fish Biol. Fish., 2018, 28, 177-190, https://doi.org/10.1007/s11160-017-9507-9.

13. Lyach, R., Remr, J. Changes in recreational catfish Silurus glanis harvest rates between years 1986-2017 in Central Europe. J. Appl. Ichthyol., 2019, 35, 1094-1104, https://doi.org/10.1111/jai.13956.

14. Proteau, J.-P., Hilge, V., Linhart, O. État actuel et perspectives de la production aquacole des poissons-chats (Siluroidei) en Europe. Aquat. Living Res., 1996, 9, 229-235, https://doi.org/10.1051/alr:1996057.

15. Copp, G. H., Robert Britton, J., Cucherousset, J., García-Berthou, E., Kirk, R., Peeler, E., Stakènas, S. Voracious invader or benign feline? A review of the environmental biology of European catfish Silurus glanis in its native and introduced ranges. Fish Fish., 2009, 10, 252-282, https://doi.org/10.1111/j.1467-2979.2008.00321.x.

16. Carol, J., Benejam, L., Benito, J., García-Berthou, E. Growth and diet of European catfish (Silurus glanis) in early and late invasion stages. Fundam. Appl. Limnol., 2009, 174, 317-328, https://doi.org/10.1127/1863-9135/2009/0174-0317.

17. Castaldelli, G., Pluchinotta, A., Milardi, M., Lanzoni, M., Giari, L., Rossi, R., Fano, E. A. Introduction of exotic fish species and decline of native species in the lower Po basin, north-eastern Italy: the decline of native fish species in the lower Po basin. Aquat. Conserv., 2013, 23, 405-417. https://doi.org/10.1002/aqc.2345.

18. Vejř́ik, L., Vejř́íková, I., Kočvara, L., Sajdlová, Z., Hoang The, S. C., Šmejkal, M., Peterka, J., Čech, M. Thirty-year-old paradigm about unpalatable perch egg strands disclaimed by the freshwater top-predator, the European Catfish (Silurus glanis). PLoS one, 2017, 12, e0169000, https://doi.org/10.1371/journal.pone.0169000.

19. Guillerault, N., Bouletreau, S., Iribar, A., Valentini, A., Santoul, F. Application of DNA metabarcoding on faeces to identify European catfish Silurus glanis diet: DNA metabarcoding of S. glanis faeces. J. Fish Biol., 2017, 90, 2214-2219, https://doi.org/10.1111/jfb.13294.

20. Vejř́́k, L., Vejř́ḱková, I., Blabolil, P., Eloranta, A. P., Kočvara, L., Peterka, J., Sajdlová, Z., Chung, S. H. T., Šmejkal, M., Kiljunen, M., Čech, M. European catfish (Silurus glanis) as a freshwater apex predator drives ecosystem via its diet adaptability. Sci. Rep., 2017, 7, 15970, https://doi.org/10.1038/s41598-017-16169-9.

21. Syväranta, J., Cucherousset, J., Kopp, D., Crivelli, A., Céréghino, R., Santoul, F. Dietary breadth and trophic position of introduced European catfish Silurus glanis in the River Tarn (Garonne River basin), southwest France. Aquat. Biol., 2010, 8, 137-144, https://doi.org/10.3354/ab00220.

22. Reading, A. J., Britton, J. R., Davies, G. D., Shinn, A. P., Williams, C. F. Introduction and spread of non-native parasites with Silurus glanis L. (Teleostei: Siluridae) in UK fisheries. J. Helminthol., 2012, 86, 510-513, https://doi.org/10.1017/S0022149X11000642

23. Rees, A. The impact of introduced European catfish (Silurus glanis L.) in UK waters: a three pond study. PhD thesis, University of Hertfordshire, Hatfield (UK), May 2020.

24. Cucherousset, J., Boulêtreau, S., Azémar, F., Compin, A., Guillaume, M., Santoul, F. "Freshwater killer whales": Beaching behavior of an alien fish to hunt land birds. PLoS one, 2012, 7, e50840, https://doi.org/10.1371/journal.pone.0050840.

25. Haubrock, P. J., Azzini, M., Balzani, P., Inghilesi, A. F., Tricarico, E. When alien catfish meet - Resource overlap between the North American Ictalurus punctatus and immature European Silurus glanis in the Arno River (Italy). Ecol. Freshw. Fish, 2020, 29, 4-17. https://doi.org/10.1111/eff.12481.

26. Ferreira, M., Gago, J., Ribeiro, F. Diet of European Catfish in a newly invaded region. Fishes, 2019, 4, 58, https://doi.org/10.3390/fishes4040058.

27. Alp, A. (2017). Diet shift and prey selection of the native European catfish, Silurus glanis, in a Turkish reservoir. J. Limnol. Freshw. Fisheries Res., 2017, 15-23, https://doi.org/10.17216/limnofish.288217.

28. Manfredi, P. Cattura di un Silurus glanis nell'Adda presso Lecco. Natura, Società Italiana Scienze Naturali e del Museo Civico di Storia Naturale, Acquario Civico Milano, Milano, 1957, pp 28-30.

29. Gandolfi G., Giannini M. La presenza del Silurus glanis nel fiume Po (Osteichthyes, Siluridae). Natura, Società Italiana Scienze Naturali e del Museo Civico di Storia Naturale, Acquario Civico Milano, Milano, 1979, pp 3-6.

30. Cerri, J., Ciappelli, A., Lenuzza, A., Zaccaroni, M., Nocita, A. Recreational angling as a vector of freshwater invasions in Central Italy: perceptions and prevalence of illegal fish restocking. Knowl. Manag. Aquat. Ecosyst., 2018, 419, 38, https://doi.org/10.1051/kmae/2018028.

31. Specchi, M., Pizzul, E. First observations of Silurus glanis (L. 1758) in the streams of the Isonzo basin (North-eastern Italy) (Osteichthyes, Siluridae). In: Gortania. Atti del Museo Friulano di Storia Naturale di Udine, Udine, 1994, pp. 213-216.

32. Capra, H., Pella, H., Ovidio, M. Individual movements, home ranges and habitat use by native rheophilic cyprinids and nonnative catfish in a large regulated river. Fish. Manag. Ecol., 2018, 25, 136-149, https://doi.org/10.1111/fme.12272. 
33. Britton, J. R., Cucherousset, J., Davies, G. D., Godard, M. J., Copp, G. H. Non-native fishes and climate change: predicting species responses to warming temperatures in a temperate region. Freshw. Biol., 2010, 55, 1130-1141. https://doi.org/10.1111/j.13652427.2010.02396.x.

34. Volta, P., Jeppesen, E., Sala, P., Galafassi, S., Foglini, C., Puzzi, C., Winfield, I. J. Fish assemblages in deep Italian subalpine lakes: history and present status with an emphasis on non-native species. Hydrobiologia, 2018, 824, 255-270, https://doi.org/10.1007/s10750-018-3621-0.

35. Vejř́í, L., Veǰríková, I., Kočvara, L., Blabolil, P., Peterka, J., Sajdlová, Z., Jůza, T., Šmejkal, M., Kolařík, T., Bartoň, D., Kubečka, J., Čech, M. The pros and cons of the invasive freshwater apex predator, European catfish Silurus glanis, and powerful angling technique for its population control. J. Environ. Manag., 2019, 241, 374-382, https://doi.org/10.1016/j.jenvman.2019.04.005.

36. Volta, P., Jepsen, N. The recent invasion of Rutilus rutilus (L.) (Pisces: Cyprinidae) in a large South-Alpine Lake: Lago Maggiore. J. Limnol., 2008, 67, 163-170, https://doi.org/10.4081/jlimnol.2008.163.

37. Salmaso, N., Mosello, R. Limnological research in the deep southern subalpine lakes: synthesis, directions and perspectives. Adv. Oceanogr. Limnol., 2010, 1, 29-66, https://doi.org/10.1080/19475721003735773.

38. Grimaldi, E. Lago Maggiore: effects of exploitation and introductions on the salmonid community. J. Fish. Res. Board Can., 1972, 29, 777-785, https://doi.org/10.1139/f72-122.

39. De Bernardi, R., Calderoni, A., Mosello, R. Environmental problems in Italian lakes, and lakes Maggiore and Orta as successful examples of correct management leading to restoration. Internationale Vereinigung für theoretische und angewandte Limnologie: Verhandlungen, 1996, 26, 123-138.

40. Galassi, S., Volta, P., Calderoni, A., Guzzella, L. Cycling pp'DDT and pp'DDE at a watershed scale: the case of Lago Maggiore (Italy). J. Limnol., 2006, 65, 100-106.

41. Volta, P., Tremolada, P., Neri, M.C., Giussani, G., Galassi, S. Age-dependent bioaccumulation of organochlorine compounds in fish and their selective biotransformation in top predators from Lake Maggiore (Italy). Water Air Soil Pollut., 2009, 197, 193-209, https://doi.org/10.1007/s11270-008-9803-z.

42. Guzzella, L. M., Novati, S., Casatta, N., Roscioli, C., Valsecchi, L., Binelli, A., Parolini, M., Solcà, N., Bettinetti, R., Manca, M., Mazzoni, M., Piscia, R., Volta, P., Marchetto, A., Lami, A., Marziali, L. Spatial and temporal trends of target organic and inorganic micropollutants in Lake Maggiore and Lake Lugano (Italian-Swiss water bodies): contamination in sediments and biota. Hydrobiologia, 2018, 824, 271-290, https://doi.org/10.1007/s10750-017-3494-7.

43. Mazzoni, M., Buffo, A., Cappelli, F., Pascariello, S., Polesello, S., Valsecchi, S., Volta, P., Bettinetti, R. Perfluoroalkyl acids in fish of Italian deep lakes: environmental and human risk assessment. Sci. Tot. Environ., 2019, 653, 351-358, https://doi.org/10.1016/j.scitotenv.2018.10.274.

44. Galafassi, S., Sighicelli, M., Pusceddu, A., Bettinetti, R., Cau, A., Temperini, M. E., Gilliber, R., Ortolani, M., Pietrelli, L., Zaupa, S.,Volta, P. Microplastic pollution in perch (Perca fluviatilis, Linnaeus 1758) from Italian south-alpine lakes. Environ. Pollut., 2021, 288, 117782, https://doi.org/10.1016/j.envpol.2021.117782.

45. Douglas, M. R., Brunner, P. C. Biodiversity of central alpine Coregonus (Salmoniformes): impact of one-hundred years of management. Ecol. Appl., 2002, 12, 154-172.

46. Hudson A., Vonlanthen P., Lundsgaard-Hansen B., Denis R., Seehausen O. Untersuchungen zur verwandtschaft der felchen aus dem Lago di Como, di Lugano und Maggiore. Rapporto tecnico per il Dipartimento del Territorio, Servizio cantonale della caccia e pesca, Bellinzona (CH), 2008.

47. Volta, P., Sala, P., Campi, B., Cerutti, I. Caratterizzazione tassonomica e funzionale della comunità ittica nel Lago Maggiore con particolare riferimento alle specie alloctone invasive di recente comparsa e alla sovrapposizione della nicchia trofica. In: Ricerche sull'evoluzione del Lago Maggiore: aspetti limnologici. CIPAIS - Consiglio Nazionale delle Ricerche, Verbania (VB), 2013, pp. $82-98$.

48. Jeppesen, E., Mehner, T., Winfield, I. J., Kangur, K., Sarvala, J., Gerdeaux, D., Rask, Malmquist, H. J., Holmgren, K., Volta, P., Romo, S., Eckmann, R., Sandström, A., Blanco, S., Kangur, A., Stabo H. R., Tarvainen, M., Ventelä A. M., Søndergaard, A., Lauridsen, T. L., Meerhoff, M. Impacts of climate warming on lake fish assemblages: evidence from 24 European long-term data series. Hydrobiologia, 2012, 694, 1-39, https://doi.org/10.1007/s10750-012-1182-1.

49. Dörr, A. J. M., La Porta, G., Pedicillo, G., Lorenzoni, M. Biology of Procambarus clarkii (Girard, 1852) in Lake Trasimeno. Bull. Fr. Pêche Piscic., 2006, 380-381, 1155-1168, https://doi.org/10.1051/kmae:2006018.

50. Endrizzi, S., Bruno, M. C., Maiolini, B. Distribution and biometry of native and alien crayfish in Trentino (Italian Alps). J. Limnol., 2013, 72, 343-360, https://doi.org/10.4081/jlimnol.2013.e28.

51. Batistić, M., Tutman, P., Bojanić, D., Skaramuca, B., Kŏzul, V., Glavić, N., Bartulović, V. Diet and diel feeding activity of juvenile pompano (Trachinotus ovatus) (Teleostei: Carangidae) from the southern Adriatic, Croatia. J. Mar. Biol. Assoc. U. K., 2005, 85, 1533-1534. https://doi.org/10.1017/S0025315405012749.

52. Hureau, J. C. Biologie compare de quelques poisons antarctiques Nothotheniidae. Bulletin De L'institut Océanographique Monaco, 1969, 68, 1-44.

53. Hyslop, E. J. Stomach contents analysis-a review of methods and their application. J. Fish Biol., 1980, 17, 411-429, https://doi.org/10.1111/j.1095-8649.1980.tb02775.x.

54. De Santis, V., Quadroni, S., Britton, R. J., Carosi, A., Roberts, C. G., Lorenzoni, M., Crosa, G., Zaccara, S. Biological and trophic consequences of genetic introgression between endemic and invasive Barbus fishes. Biol. Invasions, 2021, 1-18, https://doi.org/10.1007/s10530-021-02577-6. 
55. Costello, M. J. Predator feeding strategy and prey importance: a new graphical analysis. J. Fish Biol., 1990, 36, 261-263, https://doi.org/10.1111/j.1095-8649.1990.tb05601.x.

56. Amundsen, P. A., Gabler, H. M., Staldvik, F. J. A new approach to graphical analysis of feeding strategy from stomach contents data-modification of the Costello (1990) method. J. Fish Biol., 1996, 48, 607-614, https://doi.org/10.1111/j.10958649.1996.tb01455.x.

57. R Core Team. R: A language and environment for statistical computing. R Foundation for Statistical Computing, Vienna, Austria. 2021, https://www.R-project.org/.

58. Oksanen, J., Blanchet, F. G., Friendly, M., Kindt, R., Legendre, P., McGlinn, D., Minchin, P. R., O’Hara, R. B., Simpson, G. L., Solymos, P., Stevens, M. H. H., Szoecs, E., Wagner, H. Vegan: Community Ecology Package. R package version 2.5-6. 2019, https://CRAN.R-project.org/package=vegan.

59. Slavík, O., Horký, P., Bartoš, L., Kolářová, J., Randák, T. Diurnal and seasonal behaviour of adult and juvenile European catfish as determined by radio-telemetry in the River Berounka, Czech Republic. J. Fish Biol., 2007, 71, 101-114, https://doi.org/10.1111/j.1095-8649.2007.01471.x.

60. Daněk, T., Horký, P., Kalous, L., Filinger, K., Břicháček, V., Slavík, O. Seasonal changes in diel activity of juvenile European catfish Silurus glanis (Linnaeus, 1758) in Byšická Lake, Central Bohemia. J. Appl. Ichthyol., 2016, 32, 1093-1098, https://doi.org/10.1111/jai.13146.

61. Lenhardt, M. B., Smederevac-Lalić, M. M., Spasić, S. Z., Honț, Ş., Paraschiv, M., Iani, M. I., Nikčević, M. V., Klimley, P. A., Suciu, R. Seasonal changes in depth position and temperature of European catfish (Silurus glanis) tracked by acoustic telemetry in the Danube River. Int. Rev. Hydrobiol., 2021, 106, 191-201, https://doi.org/10.1002/iroh.202002049.

62. Slavík, O., Horký, P., Maciak, M., Wackermannová, M. Familiarity, prior residency, resource availability and body mass as predictors of the movement activity of the European catfish. J. Ethol., 2016, 34, 23-30, https://doi.org/10.1007/s10164-015-0441-9.

63. Haubrock, P. J. Seasonal variability in the diet of juvenile European catfish, Silurus glanis, in the Arno River (Italy) in Florence. Fish. Aquat. Life, 2021, 29, 54-61, https://doi.org/10.2478/aopf-2021-0007.

64. Haertel-Borer, S. S., Zak, D., Eckmann, R., Baade, U., Hölker, F. Population density of the crayfish, Orconectes limosus, in relation to fish and macroinvertebrate densities in a small mesotrophic lake-implications for the lake's food web. Int. Rev. Hydrobiol., 2005, 90, 523-533, https://doi.org/10.1002/iroh.200510819.

65. Czarnecki, M., Andrzejewski, W., Mastyñski, J. The feeding selectivity of wels (Silurus glanis L.) In lake Góreckie. Archiv. Pol. Fish., 2003, 11, 141-147.

66. Pohlmann, K., Grasso, F.W., Breithaupt, T. Tracking wakes: the nocturnal predatory strategy of piscivorous catfish. Proc. Nat. Acad. Sci. U. S. A., 2001, 98, 7371-7374.

67. Carol, J., Zamora, L., García-Berthou, E. Preliminary telemetry data on the movement patterns and habitat use of European catfish (Silurus glanis) in a reservoir of the River Ebro, Spain. Ecol. Freshw. Fish, 2007, 16, 450-456, https://doi.org/10.1111/j.16000633.2007.00225.x.

68. Wheeler, A. The fishes of the British Isles and North West Europe. Macmillan and Co., London, 1969.

69. Lever, C. The naturalised animals of the British Isles. Hutchinson and Company, Limited, London, 2007, 600 pp.

70. Guillerault, N., Delmotte, S., Boulêtreau, S., Lauzeral, C., Poulet, N., Santoul, F. Does the non-native European catfish Silurus glanis threaten French river fish populations? Freshw. Biol., 2015, 60, 922-928, https://doi.org/10.1111/fwb.12545.

71. Wasserman, J.R., Alexander, M.E., Dalu, T., Ellender, B.L., Kaiser, H., Weyl, O.L. Using functional responses to quantify interaction effects among predators. Funct. Ecol., 2016, 30, 1988-199, https://doi.org/10.1111/1365-2435.12682.

72. Wysujack, K., Mehner, T. Can feeding of European catfish prevent cyprinids from reaching a size refuge? Ecol. Freshw. Fish, 2005, 14, 87-95, https://doi.org/10.1111/j.1600-0633.2004.00081.x.

73. Bettinetti, R., Croce, V., Galassi, S., Volta, P. pp'DDT and pp'DDE accumulation in a food chain of Lake Maggiore (Northern Italy): testing steady-state condition. Env. Sci. Poll. Res. Int., 2006, 13, 59-66, https://doi.org/10.1065/espr2006.01.010.

74. Saidi, H., Dresti, C., Manca, D., Ciampittiello, M. Climate projections in Lake Maggiore watershed using statistical downscaling model. Clim. Res., 2020, 81, 113-130, https://doi.org/10.3354/cr01613.

75. Fenocchi, A., Rogora, M., Sibilla, S., Ciampittiello, M., Dresti, C. Forecasting the evolution in the mixing regime of a deep subalpine lake under climate change scenarios through numerical modelling (Lake Maggiore, Northern Italy/Southern Switzerland). Clim. Dyn., 2018, 51, 3521-3536, https://doi.org/10.1007/s00382-018-4094-6.

76. Iacarella, J.C., Dick, J.T.A., Alexander, M.E., Ricciardi, A. Ecological impacts of invasive alien species along temperature gradients: testing the role of environmental matching. Ecol. Appl., 2015, 25, 706-716, doi:10.1890/14-0545.1. PMID:26214916.

77. Denley, D., Metaxas, A., Fennel, K. Community composition influences the population growth and ecological impact of invasive species in response to climate change. Oecologia, 2019, 189, 537-548, doi:10.1007/s00442018-04334-4. PMID:30604087.

78. Volta, P., Jeppesen, E., Campi, B., Sala, P., Matthias, E., Winfield, I. J. The population biology and life history traits of Eurasian ruffe [Gymnocephalus cernuus (L.), Pisces: Percidae] introduced into eutrophic and oligotrophic lakes in Northern Italy. J Limnol, 2013, 72, 280-290, https://doi.org/10.4081/jlimnol.2013.e22.

79. Muscalu, R., Muscalu, C., Nagy, M., Bura, M., Szelei, Z. T. Studies on wels catfish (Silurus glanis) development during cold season as an auxiliary species in sturgeon recirculated aquaculture systems. Aquac., Aquar., Conserv. Legis., 2010, 3, $362-366$.

80. Larson, E. R., Graham, B. M., Achury, R., Coon, J. J., Daniels, M. K., Gambrell, D. K., Jonasen, K. L., King, G. D., LaRacuente, N., Perrin-Stowe, T. I., Reed, E. M., Rice, C. J., Ruzi, S. A., Thairu, M. W., Wilson, J. C., Suarez, A. V. From eDNA to citizen science: Emerging tools for the early detection of invasive species. Front. Ecol. Environ., 2020, 18, 194-202, https://doi.org/10.1002/fee.2162. 
81. Martelo, J., da Costa, L., Ribeiro, D., Gago, J., Magalhães, M., Gante, H., Alves, M., Cheoo, G., Gkenas, C., Banha, F., Gama, M., Anastácio, P., Tiago, P., Ribeiro, F. Evaluating the range expansion of recreational non-native fishes in Portuguese freshwaters using scientific and citizen science data. BioInvasions Rec., 2021, 10, 378-389, https://doi.org/10.3391/bir.2021.10.2.16. 